\title{
Report of gutkha (smokeless tobacco) use in children aged $10-12$ years
}

\author{
Rachappa Mallikarjuna, Rini R Gangwal, Srinivas L Shanthraj, Bhavna Dave
}

Department of Pedodontics and Preventive Dentistry, K.M.Shah Dental College and Hospital, Vadodara, Gujarat, India

\section{Correspondence to} Dr Rachappa Mallikarjuna, mmrachappa@gmail.com
To cite: Mallikarjuna $R_{\text {, }}$ Gangwal RR, Shanthraj SL, et al. BMJ Case Rep Published online: [please include Day Month Year] doi:10.1136/bcr-2012008319

\section{DESCRIPTION}

Tobacco is a risk factor for six of the eight leading causes of deaths in the world and kills up to one-half of its users. ${ }^{1}$ Tobacco use can result in a number of oral diseases. Oral cancer, ${ }^{2}$ periodontitis ${ }^{3}{ }^{4}$ compromised wound healing, a reduction in the ability to smell and taste, smoker's palate and melanosis, coated tongue, staining of teeth and restorations, implant failure and leukoplakia ${ }^{5}$ are all seen in tobacco users. Smokeless tobacco is a risk factor for periodontal conditions ${ }^{78}$ and oral cancer. ${ }^{9}$

India is the second largest consumer of tobacco products and the third largest producer of tobacco in the world. The estimated number of tobacco users in India was 274.9 million. Of these, 163.7 million use only smokeless tobacco, 68.9 million are smokers and 42.3 million use both forms of tobacco. ${ }^{10}$ The prevalence of smokeless tobacco use has increased from $24 \%$ in 1995 to $33 \%$ in $2009 .^{10}$ Smokeless tobacco use is seen in $13.4 \%$ of boys who are high school students and 2.3\% ofwomen. ${ }^{11}{ }^{12}$ Smokeless tobacco contains arecanut which may be raw, baked or boiled, lime obtained from limestone or seashells and may also include aniseed, catechu, cardamom, cinnamon, coconut, cloves, sugar and tobacco. ${ }^{13}$

We present two case reports on use of smokeless tobacco in children.

\section{Case 1}

A 12-year-old-boy presented with a chief complaint of discoloured teeth. The patient revealed a history of gutkha (smokeless tobacco) intake twice a day since 3 years (approximately started at the age of 9 years). Upon interviewing; the child reported intake of gutkha, which is a preparation of crushed areca nut (also called betel nut), tobacco, catechu, paraffin, slaked lime and sweet or savoury flavourings. It is a powdery, granular, light brownish to white substance. Within moments of consumption, gutkha begins to dissolve and turn deep red in colour hence causing stains on teeth. The patient learnt this habit of gutkha intake from his friends in his school. He complained of symptoms such as

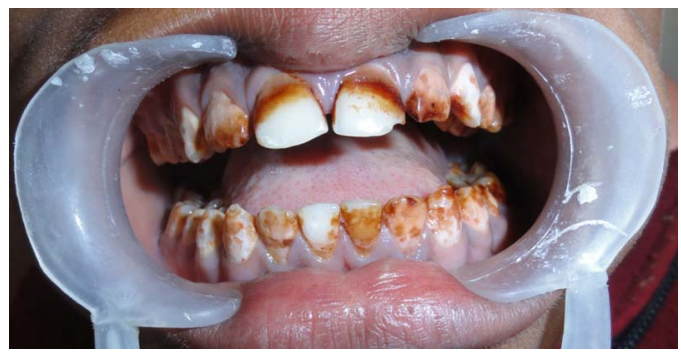

Figure 1 Labial surfaces of anterior teeth.

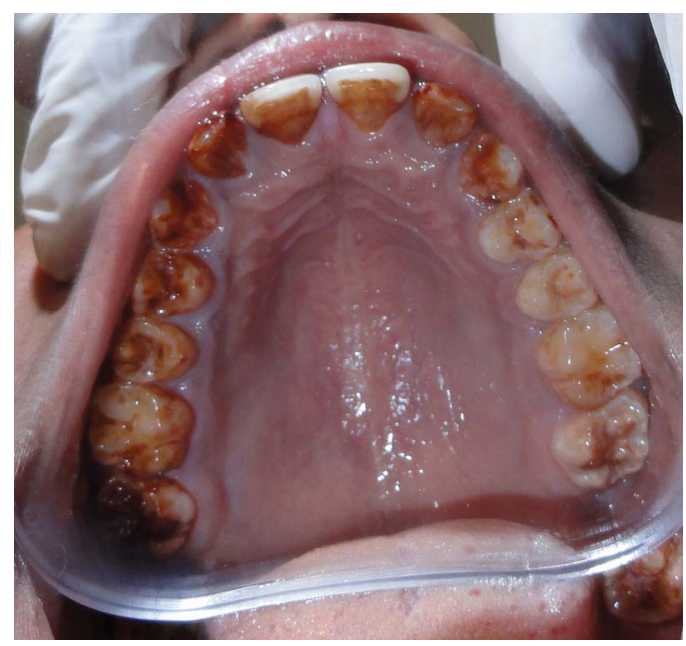

Figure 2 Occlusal surfaces of maxillary teeth.

irritation and a burning sensation in the mouth upon consumption of food and of bad breath. Upon examination, the teeth showed generalised fluorosis with stains (figures 1-3). No soft tissue changes were observed. The treatment plan consisted of oral prophylaxis (scaling and polishing of teeth) and counselling to stop the tobacco consumption. Thorough oral prophylaxis was performed and oral hygiene instructions were given.

The patient was advised for a regular follow-up every 3 months.

\section{Case 2}

An 11-year-old boy presented with a complaint of discoloured teeth. He had a history of intake of gutkha once a day since 2 years (approximately started at the age of 9 years). He learnt this habit of tobacco intake by observing his father, a farmer

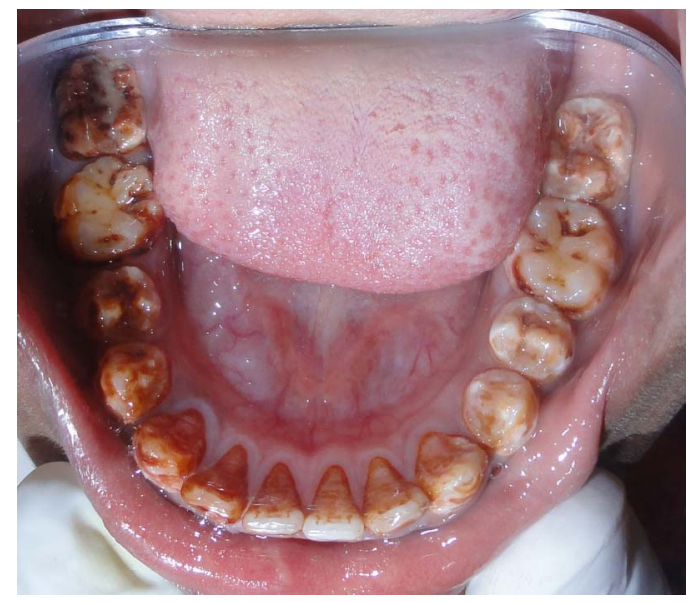

Figure 3 Occlusal surfaces of mandibular teeth. 


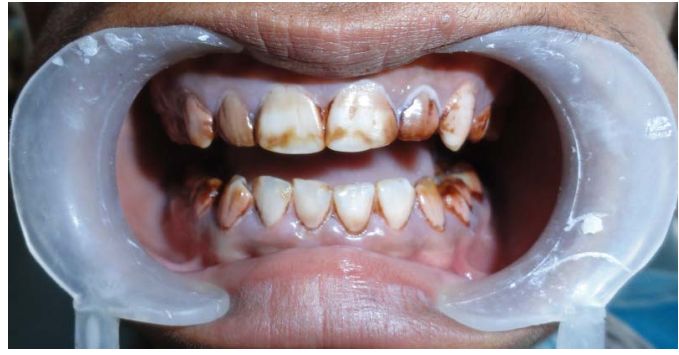

Figure 4 Labial surfaces of anterior teeth.

who consumed gutkha four times a day for 5 years. On intraoral examination, stains were present on labial and occlusal surfaces of the teeth (figures 4-6). The patient also had bad breath and revealed no other symptoms. No soft tissue changes were observed. The treatment plan consisted of oral prophylaxis along with counselling for cessation of the habit. Thorough oral prophylaxis was performed and oral hygiene instructions were given.

The patient was advised for a follow-up every 3 months.

\section{Learning points}

- Educate children, parents and guardians on the serious health consequences of tobacco use and its exposure at home.

- Instruct parents and guardians to serve as role models by not using tobacco and urging other members who use tobacco; to stop.

- Routinely examine patients for oral signs and changes associated with tobacco use.

- Dentists should work with school authorities to educate about the ill-effects of gutkha and other forms of tobacco.

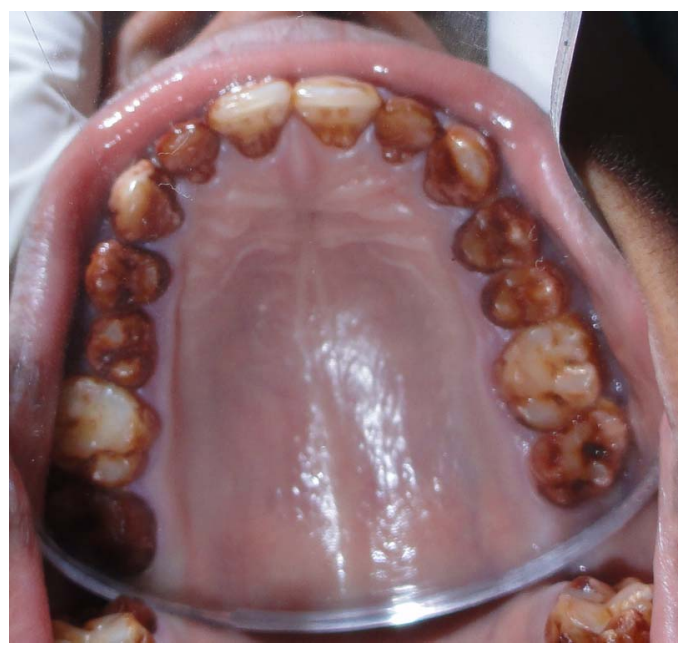

Figure 5 Occlusal surfaces of maxillary teeth.

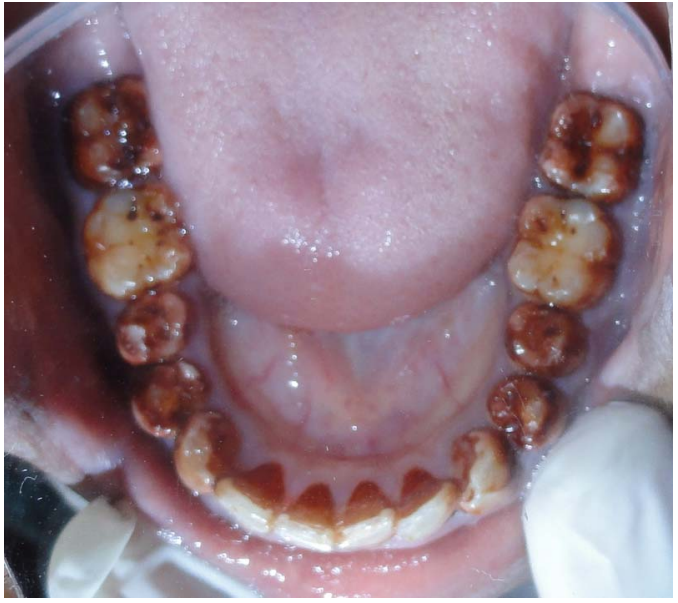

Figure 6 Occlusal surfaces of mandibular teeth.

Competing interests None.

Patient consent Obtained.

Provenance and peer review Not commissioned; externally peer reviewed.

\section{REFERENCES}

1 World Health Organization. Tobacco key facts. http://www.who.int/topics/tobacco/ facts/en/index.html (accessed 11 Dec 2012).

2 US Dept. of Health and Human Services. The health consequences of involuntary exposure to tobacco smoke: a report of the Surgeon General. US Dept of Health and Human Services, CDC, National Center for Chronic Disease Prevention and Health Promotion, Office on Smoking and Health, Atlanta, GA. 2006. http://www. surgeongeneral.gov/library/secondhandsmoke/report/chapter1.pdf (accessed 11 Dec 2012).

3 Johnson GK, Hill M. Cigarette smoking and the periodontal patient. J Periodontol 2004;75:196-209.

4 Bergstrom J, Eliasson S, Dock J. A 10-year prospective study of tobacco smoking and periodontal health. J Periodontol 2000;71:1338-47.

5 Vellappally S, Fiala Z, Smejkalova J, et al. Smoking related systemic and oral diseases. Acta Medica 2007;50:161-6.

6 Reibel J. Tobacco and oral diseases. Update on the evidence, with recommendations. Med Princ Pract 2003;12(Suppl 1):22-32.

7 Monten U, Wennstrom JL, Ramberg P. Periodontal conditions in male adolescents using smokeless tobacco (moist snuff). J Clin Periodontol 2006:33:863-8.

8 Kallischnigg G, Weitkunat R, Lee PN. Systematic review of the relation between smokeless tobacco and non-neoplastic oral diseases in Europe and the United States. BMC Oral Health 2008;8:13-33.

9 Rodu B, Jansson C. Smokeless tobacco and oral cancer: a review of the risks and determinants. Crit Rev Oral Biol Med 2004;15:252-63.

10 International Institute for Population Sciences (IIPS) and Ministry of Health and Family Welfare (MoHFW). Global adult tobacco survey (GATS) India 2009-2010. Mumbai and New Delhi: IIPS and MoHFW, Government of India, 2010. http://www. searo.who.int/linkfiles/regional_tobacco_surveillance_system_gats_india.pdf (accessed 11 Dec 2012)

11 CDC. Smoking and tobacco use: Surveys: 2006 National Youth Tobacco Survey and key prevalence indicators. http://www.cdc.gov/tobacco/data_statistics/surveys/nyts/ pdfs/indicators.pdf (accessed 11 Dec 2012).

12 CDC. Smoking and tobacco use: Youth and tobacco use: Current estimates. http://www.cdc.gov/tobacco/data_statistics/fact_sheets/youth_data/tobacco_use/ index.htm\#estimates (accessed 11 Dec 2012).

13 Peter S. Essentials of preventive and community dentistry. 3rd edn. New Delhi: Arya Publishers, 2007:457. 
Copyright 2013 BMJ Publishing Group. All rights reserved. For permission to reuse any of this content visit http://group.bmj.com/group/rights-licensing/permissions.

BMJ Case Report Fellows may re-use this article for personal use and teaching without any further permission.

Become a Fellow of BMJ Case Reports today and you can:

- Submit as many cases as you like

- Enjoy fast sympathetic peer review and rapid publication of accepted articles

- Access all the published articles

- Re-use any of the published material for personal use and teaching without further permission

For information on Institutional Fellowships contact consortiasales@bmjgroup.com

Visit casereports.bmj.com for more articles like this and to become a Fellow

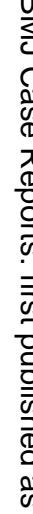

